\title{
Smart grids and the constitution of solar electricity conduct
}

\author{
Environment and Planning $\mathrm{A}$ \\ 2016, Vol. 48(I) 7-23 \\ (C) The Author(s) 2015 \\ Reprints and permissions: \\ sagepub.co.uk/journalsPermissions.nav \\ DOI: $10.1177 / 0308518 \times 15596748$ \\ epn.sagepub.com
}

@SAGE

\section{Harriet Bulkeley}

Department of Geography, Durham University, UK

\section{Gareth Powells}

School of Geography, Politics and Sociology, Newcastle University, UK

\section{Sandra Bell}

Department of Anthropology, Durham University, UK

\begin{abstract}
In the face of challenges of energy security, low carbon transitions and the replacement of aging infrastructure networks, new logics for the development of smart electricity systems are emerging amongst utility providers and public authorities. Whilst often portrayed as a technical matter, orchestrated through the top-down intervention of major corporate or government actors, such shifts in the system of electricity provision also entail efforts to fundamentally reconfigure relationships between providers and consumers, and rearticulate energy practices so that they are aligned to new governmental rationales. In this paper, we draw on theories of governmentality and social practice to consider the ways in which the smart grid is serving to constitute new forms of energy conduct, which in turn are vital to the ways in which smart grids are realised. Through the analysis of the first findings from an industry regulator-funded project in the north of England, we consider how and with what implications households that have installed solar photovoltaic (PV) technologies are fitting smart grid techniques and devices into their everyday practices. We argue that in contrast to households where solar PV has been regarded primarily as a device to deliver new flows of finance, the introduction of smart grid logics through the installation of in-home displays and hot water storage has served to rearticulate what 'good' electricity conduct entails and to reconfigure the ways in which energy-intensive practices are undertaken in households. We find these new forms of 'governing the self' to be critical in shaping how, and to what effect, the smart grid is taking root.
\end{abstract}

\section{Keywords}

Smart grid, governmentality, conduct, solar PV, practice theory

\section{Corresponding author:}

Gareth Powells, School of Geography, Politics and Sociology, Newcastle University, Daysh Building, Claremont Road, Newcastle upon Tyne NEI 7RU, United Kingdom.

Email: gareth.powells@newcastle.ac.uk 


\section{Introduction}

The UK faces the challenge of having to renew its ageing electricity infrastructure, increase the volume and variety of distributed generation sources, and support low- or non-carbon energy systems in an affordable, safe and environmentally sound manner. In particular, this will imply a change in control philosophy towards active network management and two-way flows of electricity needed to provide 'green' electricity in liberalised markets. (Lehtonen and Nye, 2009)

Located at the intersection of policy debates on the need to decarbonise energy provision in response to climate change, energy security and the future sources of generation capacity, and how to finance the renewal of ageing infrastructure networks, the future design, organisation and delivery of electricity networks has attracted widespread public debate. In the UK, as elsewhere, various protagonists, from across the public, private and third sectors, have sought to promote the 'smart grid' as offering a potential solution to this network crisis. As Lehtonen and Nye (2009) suggest, smart grids - electricity networks that are intelligent and able to provide active network management - are seen as a principal means through which to green the network and sustain provision. Given the centrality of the electricity network to modern societies, it is perhaps "not surprising that the promise of smart grids has created real hype' with significant investments in research and development taking place across Europe, the US, Australia and Asia in particular (Verbong et al., 2013: 2).

Whilst the particular configurations of smart grids vary in important ways, in terms of the network architectures and sociomaterial assemblages involved, at the heart of this phenomenon is an apparent shift in the fundamental logic of electricity provision. Whereas, the emergence and development of existing electricity networks have been seen to be guided by a logic in which supply is managed to meet demand, a smart grid relies on the apparently counterintuitive proposition that demand must also be reconfigured in order to meet supply. As such, smart grids represent a fundamental change in the nature of energy infrastructures and the relations between providers and consumers they embody that require a concomitant shift in how energy demand is managed and governed. Rather than being orchestrated around specific technologies or forms of network management, it is through this change in the logic governing how the electricity network is understood and conducted that smart grid is emergent. In this paper, we focus on how this emerging logic is configuring the conduct of solar electricity in the UK by shaping new requirements for how power is used within the home. Whilst the workings of electricity networks may seem a technical matter, we argue that by they are also a site through which the politics of governing society and the constitution of everyday practice takes place (Rutherford and Coutard, 2014).

Solar power is not a new phenomenon in the UK, but its uptake at scale has been triggered by the recent introduction of feed-in tariffs designed to increase the generation of renewable energy and enable the government's intention to meet long-term targets to decarbonise the energy generation system whilst maintaining security and affordability of supply (Smith et al., 2013). This measure was introduced within a power system in which the grid is organised and regulated in order to deliver power generated in one place to distant centres of consumption. Under the logic of increasing renewable energy production, panels were seen to have value in as much as they generate electricity in order to supply renewable electricity upstream to the market where consumers then purchase this power. Through such arrangements, the uptake of solar at scale could both potentially reduce the cost of power and provide new low-carbon sources of electricity that would also ease concerns about the security of supply. This system works by virtually transferring solar PV from one spoke of the grid where it is produced through the centralised hub of energy companies to another 
spoke of the grid where it is consumed. This separation of the production and demand for (renewable) electricity serves to create markets for power, either for specific 'green' products or as part of the general electricity pool sold to consumers (Barry and Slater, 2002; Callon et al., 2002; MacKenzie, 2008). Within this production logic, there is no explicit concern for how such electricity is used beyond the notion that particular markets can be produced through which solar electricity can be sold for premium prices. How solar-generated power is itself used is not a problem that requires resolution.

However, with the emergence of the smart grid logic, solar electricity production comes to be seen in different terms. Rather than being a neutral form of renewable electricity production, domestic scale PV panels, like other sources of renewable energy, present particular problems for power distribution. On the UK's low-voltage networks, PV power generation does not coincide with the peak in electricity consumption, as PV generation declines as the early evening peak in demand rises. It is not available at the times of highest demand. By the same token, 'un-used' solar power creates load on the network as it is exported during the day that could potentially place a strain on network infrastructure designed only to carry the power required by domestic household demand. Furthermore, whilst the UK low-voltage networks are designed to facilitate radial flows of power out from 'centres' - sub-stations - down through feeders to homes and businesses, PV introduces new power sources at the ends of wires introducing the risks of voltage imbalance and steadystate voltage rise (Wang et al., 2012). Such issues cannot be managed by attending only to the production of electricity, but also require the management of demand. As a governmental programme, the notion of smart grid seeks to minimise the potential network effects of the emergence of renewable electricity by orchestrating demand, in this case through seeking to persuade PV owners to use their own power rather than export it, and constituting users as playing a role in the 'micro' management of the grid.

Rather than viewing the emergence of these new forms of orchestrating and intervening in the grid as merely technical matters, such materialities matter to the ways in which the politics of energy transitions are constituted, enacted, given meaning and contested (Barry, 2013; Rutherford and Coutard, 2014). To engage with the politics of smart grid, we suggest that such interventions in the governing of energy use can usefully be understood through the lens of governmentality, given its central concern with the 'conduct of conduct' as the means through which governing takes place (Walters, 2012), and social practice theory, which examines the ways in which the social world is animated through practice (Shove et al., 2012). Starting from a view of the electricity network as sociotechnical, in the first part of the paper, we argue for an approach that recognises that infrastructural arrangements are not only critical to the functioning of social practices but constitutive of them, whilst similarly social practices co-constitute the electricity network. From this starting point, we consider what it might mean to regard the smart grid not as a physical entity but rather as a governmental programme that attempts to order and direct electricity systems, drawing from the field of governmentality studies to consider the means through which the governing of energy systems might be pursued and contested by means of conducting conduct. We find this interaction between theories of social practice and of governmentality productive, particularly in drawing attention to how governing is both achieved through and targeted at social practices.

In the second part of the paper, we draw on empirical work conducted as part of the Customer-Led Network Revolution (CLNR) project, an industry-led smart grid demonstration project in the UK, to examine how the rationalities, techniques and artefacts of the smart grid come to interact with the domestic energy contexts and practices of households with solar PV panels. After introducing the project and its 
methodology, we explore how and why smart grid interventions have and have not entailed a reconfiguration of practices by considering the ways in which they have sought to foster new forms of electricity conduct in line with the emerging narrative of the smart grid. We find that in the context of the UK's feed in tariff (FiT), households have indeed come to regard $\mathrm{PV}$ as a matter of producing power and feeding it back into the grid in order to secure financial reward. In contrast, the governing of solar as part of the smart grid - mediated through specific techniques and devices undertaken through the CLNR project - served to reorientate what constitutes appropriate solar conduct towards creating a closed loop between the generation of power and its consumption within the household in line with the logic outlined above. These new forms of conduct are worked through the reconstitution of everyday practices, such as washing clothes and taking showers, such that the meaning and reproduction of energy demand are reconfigured. We suggest that not only is this giving rise to new forms of provider-consumer relationship, but critically that such forms of 'smart' energy practice are in turn serving to shape how the smart grid is realised.

\section{Systems of electricity provision and the governing of social practices}

Infrastructure networks, from transportation to telecommunications, sewers to distributed energy networks, have undergone a revival within the social sciences over the past decade alongside the development of a vocabulary that refers to such networks as sociotechnical, reflecting the 'seamless web' of social and technical elements that encompasses them (Hughes, 1993). The palatability of the term sociotechnical means that it has gained significant ground, providing a focus for research and debates at the intersection of traditional disciplines. However, as with many such terms, the gloss of its widespread acceptance masks nuances in how it is variously used and understood. In some accounts, the term sociotechnical is used to signify the composite nature of such systems - as comprised of multiple different elements. These accounts offer an arguably richer realisation of infrastructure networks than is presented by those that faithfully segregate the engineering, economic, political and cultural aspects of, for example, energy services. However, they have for the most part served to sustain a model of the energy system whereby demand and supply occupy separate spheres (Shove and Walker, 2010). An alternative approach regards infrastructure systems as co-constituted through the continual interrelation of the diverse elements of which they are comprised (Rydin et al., 2013). Such a perspective offers a more open-ended and multiple account of the dynamics and durability of energy systems, and presents ways of interrogating how and why the relations between the social and the technical come to matter in stabilising systems of provision. From this view, any neat separation of supply in relation to one set of actors and technologies from demand is difficult to sustain. As Mitchell (2008) argues, 'the development of domestic electric lighting did not respect such categories. It depended upon networks that tied together humans and electrons, the flow of electric current and the flow of capital, imagination and illumination, the calculation of the cost of copper wiring and of its conductivity'. The provision of electricity is here intimately related to the production of demand, whilst forms of consumption are equally written into the system of provision such that 'consumers and providers are not only in relationships of organisational co-dependency, but... these relationships can be reinforced and reproduced by the technologies in place' effecting their 'co-conscription' in the production of particular modes of electricity provision (Chappells and Shove, 2004).

In seeking to understand these dynamics, theories of social practice have emerged as a critical means through which to interrogate the ways in which systems of provision are 
animated and sustained. There is no accepted definition of a social practice, but may researchers adopting this approach would agree, as do we, that practices are 'routinized' and socially shared behaviours (Reckwitz, 2002), which consist of the connected elements of 'meanings', 'competences' and 'materials' (Shove et al., 2012). Viewing the social world as comprised by and through practices, theorists sought to understand how 'practices evolve, how they capture and lose us, their carriers, and how systems and complexes of practice form and fragment' (Shove, 2010). This has proven to be fertile ground for social researchers in the environment and energy field seeking to move beyond behaviour change to explore how and why patterns of resource consumption endure and change. Rather than being a matter of the consumption of resources by individual agents, the 'recurrent reproduction' of social practices (Shove and Walker, 2010: 474) is considered as the means through which 'specific socio-technical regimes for the provision of water and energy to householders' are reproduced (Spaargaren, 2011).

Despite the considerable debate and advances in thinking that have emerged as a result of this productive engagement, necessarily briefly summarised here, the question of how, if at all, social practices can be considered to be governed has only recently been explored (Shove and Walker, 2010). As such, there has been little interrogation of how forms of governing are involved in the reproduction of social practice, and, in turn, how social practice may shape the ways in which governing is conducted. Addressing these issues requires an approach that can examine how 'the capacity to promote, mobilise and configure' (Shove and Walker, 2010) the requisite elements of social practices is assembled and worked out. We find that the broad body of work on governmentality, drawing on and developing Foucault's original conception (Foucault, 2009), provides useful insight into the nature and orchestration of capacity in these terms. Within the diverse body of work on governmentality, such capacity is thought of in terms of the ability to govern, which in turn is achieved through structuring the field of possible action in particular ways (Hörnqvist, 2010). Governing is conceived as taking place through programmes that seek to 'direct conduct or intervene in social processes to produce desired outcomes and avert undesired ones' ( $\mathrm{Li}, 2007: 264)$. The capacities through which the elements of social practice are assembled, configured and contested may then at least in part be derived from governmental programmes that seek to intervene to assemble particular domains to be governed around problems that are seen to need intervention and the forms of improvement that are regarded as desirable.

From this perspective, the smart grid is not a set of policies to be implemented or structures to be built, but rather a governmental programme that arises from logics that marry the imperatives for decarbonisation, security and affordability with concerns surrounding infrastructure investment. The work of establishing the smart grid therefore requires particular ways of thinking about what the electricity problem is and what desirable electricity futures might involve. This in turn involves establishing the techniques, artefacts and devices through which particular forms of electricity provision that accord with this dynamic of problematisation and improvement can be maintained (and are contested). Central to the workings of such programmatic efforts are 'governmental technologies' or techniques that "both make rationalities "visible" and permit their extension through time and space' (Murdoch, 2000). Such technologies are seen as 'mobile, stable and capable of aggregation, so that they allow governing to take place "at a distance" from governing agencies' (Bulkeley et al., 2007). Critically, however, governmental technologies do not merely reflect particular rationalities, but serve to actively constitute 'the domains which are to be governed' (Murdoch, 2000) and to constitute and mobilise forms of subjectivity (Raco, 2003). Both the objects to be governed - in this case 'the grid', solar panels, particular forms of electricity flow and so forth and - the subjects through which this is to be 
accomplished - solar electricity producers and consumers - are therefore not pregiven, but constituted through the workings of particular governmental programmes. In seeking to analyse how such forms of governing are conducted, our interest is not in tracing abstract rationalities that give rise to particular governmental configurations. The study of governmentality has often been dominated by a broad concern with how neoliberalism, as an ideology, has come to shape governmental programmes and the techniques that are enacted in ways that are often overdetermined. We agree with those who find that 'the dominant tendency to focus on governmental rationalities' in such analyses 'contributes to a view of power as top down, totalizing and omnipresent' to the neglect of the messy actualities of governmental practice. The question that we seek to address is not then whether one form of power (government) has replaced another (discipline), nor with how government operates 'at a distance' to govern individuals in accordance with particular ideologies (neoliberalism), both approaches that are associated with studies of governmentality. Instead, we take what $\mathrm{Li}$ (2007) terms an 'analytics of assemblage' approach to ask how governmentality operates, focusing on the practices through which governmental programmes seek to establish the "right way of arranging (disposer) things in order to lead (conduire)... not to the form of the "common good"... but to a "suitable end," an end suitable for each of the things to be governed' (Foucault, 2009: 99).

To this end, we seek to use the insights provided by the broad concept of governmentality and its engagement with practice theory to turn our attention to what has been described as 'governmentality literature's "Achilles' heel", namely its lack of attention to multiplicity and context' and the 'the actual processes through which subjectivities .... are formed' (Brady, 2014: 13). In pointing to the ways in which governing is conducted through the mundane and material elements of everyday life, and the formation/resistance of different subjectivities in relation to various governmental programmes, the notion of governmentality raises some intriguing issues about the ways in which social practices come to be constituted. First, it suggests that social practices are not only self-generating and perpetuated through their constant reproduction in society at large, but may result from (multiple) governmental programmes that have been more or less present historically and are geographically varied. Governmental programmes are not only related to state institutions, but rather the designers of such programmes may be many and various, operating across different scales and with differential reach, and operating through the sociomaterial world.

Second, the malleability, or otherwise, of social practices, is clearly central to the successful realisation of governmental programmes. Understanding how and why social practices might change is subject to significant debate, not least because of the consequent implications for various environmental and resource concerns. Given the importance of governmental technologies to the workings of governmental programmes, discussions within the social practice field on the importance of various material 'things' are illuminating. For the most part, materials are seen to be a critical ingredient of practice, establishing working configurations of practice and being significant in their reproduction or demise (Shove et al., 2012). Things, as constitutive of social practice 'do not figure in isolation but...they "hang together" in specific ways' (Schatzki, 1996; Spaargaren, 2011) creating forms of lock-in and social inertia. Where new things are introduced - here, through the intervention and orchestration of governmental programmes - what matters is 'the levels of fit or misfit the new products show with respect to the existing portfolios of objectives, bodies and meanings involved in the practice' (Spaargaren, 2011: 817). Social practice theories therefore suggest that governmental programmes may be more or less successful depending on the extent to which the things that constitute the techniques of governing - we 
might think of leaflets, electricity meters, solar panels, energy bills and so on - can be appropriated, normalised, incorporated into or domesticated within existing practice. Writing on governmentality suggests that these processes of normalisation take place through a variety of routes, including forms of self-government as they are encouraged to take responsibility (and live with the consequences) of their own conduct (Hörnqvist, 2010). At the same time, the conduct of conduct is always provisional, open to contestation and reversal, such that techniques are appropriated towards different ends, alternative entities come to be incorporated in the governing of conduct, and new forms of subjectivity are constituted in relation to fields of intervention, in turn reassembling what should be governed.

If governing 'requires the assemblage or alignment not only of diverse social actors but of materials, artefacts, infrastructures and so on, in order both to circumscribe the object to be governed and to achieve the "right disposition of things" within which subjectivities are forged' (Bulkeley and Schroeder, 2011) the dynamics of practice may be less about the extent to which things come to 'fit' in which social practice, than of their agency in realigning what it is that practice comprises. In the case of the smart grid, forms of washing practice that, for example, come to encompass new things like solar PV panels, smart meters and in-home display (IHD) devices maybe performed in different ways, through different social relations, and at different times of the day, serving to reconstitute what it is that washing involves as a social practice. In terms of the ways in which such practices work with and through the wider sociotechnical electricity grid, they could in turn contribute to the co-constitution of an altogether different kind of network, such as one with different physical properties, e.g. one without local voltage problems, and where relationships between those who provide electricity and those who use it are reconstituted.

In drawing across the perspectives of governmentality and social practice theory, we suggest that the smart grid can be regarded not only as a new assemblage but also as a new governmental programme. The attempt to bring into being smart grids involves at the household level the introduction of new (sets of) things into everyday forms of social practice, alongside a more active subjectivity in which households are imagined as micromanagers of the grid. The successful making of the smart grid requires then that such things are aligned by these new subjectivities and that together these developments modify existing practices. A governmental reading suggests that forms of self-government are critical in enacting this process, and serve to conduct practices in line with new notions of what the proper conduct of electricity use might involve - when, where, how and for what it should be used, and what its use signifies in a wider web of social relations and norms. Such forms of subjectivity are critically dependent not on the pervasiveness of power and control, but rather on the conditioning of freedoms such that several modes of response are possible, some of which may contradict those which were originally intended (Foucault, 2000: 342; Lockwood and Davidson, 2010: 390). This analysis suggests that smart grid interventions are most likely to be successfully appropriated into social practices where they both succeed in 'fitting' in sociotechnical terms with existing practice, and where they are able to engender new forms of electricity conduct that accord with the rationality of smart grid. However, rather than regarding governmental programmes as blueprints handed down from a distance, fixed in their designs and coming to rest in particular locations, this reading also suggests that they require continual forms of reproduction and recalibration, and are far from secure in their accomplishment ( $\mathrm{Li}$, 2007; Rutland and Aylett, 2008). 


\section{Researching smart grids}

In the context of growing interest in smart grids, the UK energy markets regulator, Ofgem, developed a programme for supporting innovation and demonstration projects in this area the Low Carbon Network Fund. This paper is drawn from research conducted as part of one of these projects: the CLNR that ran from January 2011 until December 2014. Led by Northern Powergrid, the Distribution Network Operator for the Humber, Yorkshire and North-East of England (formerly CE Electric UK), together with British Gas, one of the largest energy suppliers in the UK, EA Technology Limited, Newcastle and Durham Universities, the CLNR project was unique amongst Low-Carbon Network Fund projects in having a team of social scientists embedded within the project. The core objectives of the project were to understand the current and future load and capacity of the electricity network, and to examine the potential for customer and network flexibility as a means of avoiding the costs of reinforcing network capacities. Over 14,000 energy customers participated in the project, with the majority forming a control group that included 9000 domestic and 1850 business customers, all of which had smart meters that enable the recording of half-hourly energy consumption data. A further 21 trial groups within the project involved interventions that variously combined low-carbon technologies, tariffs, storage and IHD devices. All customers participating in the trial able to provide email contact details were invited to answer a survey about their sociotechnical context, attitudes to energy consumption and their energy use habits resulting in over 1284 responses from households and 152 responses from businesses. Further, 250 qualitative, face-to-face research visits to customers were undertaken with 131 households, 62 of whom were visited in both summer and winter research phases, and 57 businesses to study the ways in which they use energy and their consideration of the potential and limitations of being flexible in energy use.

This paper draws on a subset of the qualitative energy research visits, which included semi-structured interviews and home energy tours conducted with households with solar PV panels. Participants in the social science research were recruited from the three trials in the CLNR projects involving solar electricity producers, which together had a total of 323 participants (Table 1). Some 31 participants agreed to be involved in the research, and of these 15 agreed to a follow-up visit, making a total of 46 visits. The in-depth and qualitative nature of the research provided the opportunity to hear from participants in their own terms about how and why they used electricity and to allow them to explain in their own terms the ways in which solar electricity had come into their homes through the use of semi-structured

Table I. Research participants.

\begin{tabular}{lll}
\hline & $\begin{array}{l}\text { Number of households } \\
\text { taking part in the trial } \\
\text { and submitting } \\
\text { consumption data }\end{array}$ & $\begin{array}{l}\text { Number of } \\
\text { individual households } \\
\text { interviewed as part } \\
\text { of qualitative research }\end{array}$ \\
\hline $\begin{array}{l}\text { Group I - PV and consumption display device } \\
\begin{array}{l}\text { Group 2 - PV and generation consumption } \\
\text { display devices }\end{array}\end{array}$ & 150 & 13 \\
$\begin{array}{l}\text { Group 3 - PV, automated hot water } \\
\text { heating and consumption display device }\end{array}$ & 66 & 13 \\
$\begin{array}{l}\text { Total } \\
\text { otal }\end{array}$ & 323 & 31 (plus I5 follow-up visits)
\end{tabular}


interviews. Visits typically lasted 60 to 90 minutes. The home tour had the added value of allowing participants to demonstrate their home - to show the sites and artefacts through which they engaged with electricity and how in turn solar electricity made a difference to the ways in which they used their home. Qualitative data were recorded on digital voice recorders, digital cameras and in some cases iPads and was collated, organised and thematically coded in NVivo 9.

Together, these methods provided insight into the sociotechnical constitutes of solar electricity in the home. Whilst the sample of participants is smaller than one recent study (Keirstead, 2007), which involved a survey of 118 households with follow-up interviews for 63 participants, the method provides more scope for the perspective of participants to lead the inquiry with follow-up detailed interviews enabling a discussion of how things change over time. Another recent study in the UK involved a sample of 37 households using two different PV systems (Abi-Ghanem and Haggett, 2011), but to our knowledge, no other studies of this kind have taken place. In our research, the participants were from three different trials each of which involved a different configuration of PV, smart meters and smart grid interventions. One group of participants had only the PV panel and an IHD showing their energy consumption (Test Cell 5), a second group had PV panels and an inhome traffic light display that provided information about the amount of solar power available for consumption (Test Cell 20 manual), whilst a third group had a hot water tank that could automatically absorb power that would otherwise be exported (Test Cell 20auto). The numbers of participants in each group are set out in Table 1. Drawing on this data, in the remainder of the paper, we turn to examine how such interventions have sought to establish new forms of electricity conduct and have been accommodated, and resisted, within existing forms of social practice.

\section{Solar conduct in the smart grid: From investment to smart use?}

Rather than being focused on the generation of PV power, the logics of smart grid rest on matching demand to supply such that resources generated locally are used on site. Rather than simply exporting their power generation in return for financial gain, these logics require households to engage with the production of solar energy and its fluctuations and the practical affordances offered by new configurations of devices, rationales and competences in order to reduce the impact on the grid. Through our research, we find that whilst the logic of solar as investment written in and through the use of techniques such as the FiT and renta-roof schemes has come to shape the conduct of solar power within some households, as the economy of the FiT has changed serving to reduce the value of exported electricity, so too has the imperative to use solar on site comes to the fore. Smart interventions benefit from this changing context, and serve both to reinforce the viability of local consumption and to introduce new norms about what constitutes good solar conduct. In the remainder of this section, we first examine how solar power has come to be seen as a vehicle for private investment before considering how interventions intended to improve solar electricity in line with the smart grid logic that seeks to encourage its on-site use - enhanced displays and automatic hot water heating - have come to be fitted within domestic practices and hence reconfigure electricity conduct in line with a logic of 'solar as smart'.

\section{FIT and forget? Solar PV and investment rationales}

After a long and varied history of experimentation in the UK, domestic scale solar generation has become increasingly popular since the 2010 introduction of the FiT, which 
served to make solar PV an attractive investment proposition (Smith et al., 2013). So much so that total generation from domestic scale PV grew from $310 \mathrm{mWh}$ in $2010 / 2011$ to $811 \mathrm{mWh}$ in 2011/2012 (Change, 2013).

The FIT, it weren't for the FIT it wouldn't make sense to put PV panels up. You've got to have something, as well as feeling good, you've got to have some financial incentive. (DL17 - PV only) It's the fact that it's given us that bit extra towards us pensions. (DL14 - PV only)

The quotations demonstrate how powerful the potential return on investment was in influencing the installation of PV + FIT. The FiT was introduced in the context of low interest rates and insecurity about housing and financial markets, so that PV came to be regarded as one of the most secure and profitable forms of investment for householders during 2010-2011, as championed in the financial press (Louth, 2013; Which, 2013). The investment logic of PV in turn serves to create a focus on maximising generation with little regard for whether power is exported or used on site. The goal is simply to generate, to 'fit and forget' the PV panels and manage the financial flows associated with them:

I got an income of $£ 1600$ and an outlay of around $£ 1000$ so I was getting $£ 600$ more than I was using. In terms of what I paid and what I'm getting back from it there's nowhere I would get the same income with security. For 25 years... and I think 25 years will probably see me out! (DL15 - PV only)

Households with PV but no other intervention (Test Cell 5 in our study) were noticeably engaged in forms of calculating and recording their own energy use and production in ways that were not visible across the rest of our sample. Here the focus was not so much on the conduct of energy, but on the ways in which PV at home serves to create new forms of personal finance (see also Smith, 2008):

At the time it was after the crash of '08 and I came out of the health service. I was looking for somewhere to put my lump sum on retirement and instead of putting it in stocks and shares I put it on the roof! And I got the maximum tariff. (DL19 - PV only)

I don't know 'nowt about the technology, but it's nice to get that amount for your electricity. Every pensioner should have it as standard. (DL21 - PV only)

For most people in Test Cell 5, owning a PV array had not led them to modify their major household practices. Instead they associated the PV panels with a revenue stream and developed techniques for monitoring these that were more akin to other financial management techniques than energy management measures. For example, participants had created records of generation and consumption that resembled statements of accounts and these were used to make financial flows visible, but there was little linkage made between these records and the modification of energy use in the home:

I check it every day. I've got all the stats since we got it, the monthly stats.... When the number goes round, that's how many units we've brought in, and shoved out to the grid. (DL20 - PV only)

Furthermore, despite an avid interest in monitoring the flows of finance generated through $\mathrm{PV}$, we encountered little by way of engagement with how to ensure that they gained the most from their installation amongst these households. In most cases, PV was bought as a 'black box' financial product, much as would be the case with other financial investments such as bank or building society products, and whilst the flows of finance that it generated came to be understood in relation to household economies and future plans, the installation itself was of little interest. However, the economy of PV installation has changed 
considerably since the initial introduction of the FiT, in turn creating the potential for new ways of relating PV to the workings of households. The guaranteed floor price paid for PV generated power has fallen from $43.3 \mathrm{p} / \mathrm{kWh}$ in 2010 to $14 \mathrm{p} / \mathrm{kWh}$ in 2013 , whilst the price paid for exported energy is index linked to the UK's retail price index, making it static in real terms. As well as these changes to the price itself, the duration of the guaranteed FiT has fallen from 25 years to 20 years. Taken together, the effect of these changes is that the income generated by PV panels is diminishing. As a result, investments in new PV installations will come to rely on the money saved by using power on site rather than the money earned through the FiT. This is because using the energy in the home will mean that households have to buy less energy from their supplier. Because the FiT is diminishing and energy prices are likely to rise, the benefits of using PV generated energy in the home are only likely to increase (Bolton, 2013). In this way, the success or otherwise of PV installations will come to depend not only on the ways in which it can reconfigure flows of household finance, but on the extent to which it is able to reconfigure household practices that use electricity. In this way, the logics underpinning the installation of PV are becoming more closely aligned with those of the smart grid, sharing an interest in the management of household energy demand in relation to the supply of electricity.

\section{From monitoring to management: Equipping practices for flexibility}

In Test Cell 20 of the CLNR project, participants were either given an IHD which communicated the levels of electricity that were being imported or exported from their PV or were provided with a hot water system that would automatically divert any excess power being generated by the PV but not used in the home to heat a tank of water (TC20a). These artefacts provide a means through which the governmental programme of the smart grid is constituted through techniques capable of shaping the conduct of households. In so doing, households are encouraged to make use of local power requiring them, in different ways, to become a comanager of the low-voltage network such that their conduct has consequences not only for the electricity network but for their local community. By using solar-generated electricity at home, users reduce the risks of load and voltage problems on local networks both enabling more households in their community to use PV (by using less of the collective resource of the network) and reducing the potential impacts of their installation (in terms of voltage rises causing power outages and infrastructure damage). Central to achieving this realignment of relations between the grid, community and household are forms of selfgovernment in which participants adopt and internalise smart grid logics, rather than being coerced into new top-down disciplinary regimes. This active management of domestic production and consumption is a clear departure from the passive, 'fit and forget' PV ownership observed above, and is a new feature of how PV ownership intervenes in everyday life for those taking part in the intervention trial (Test Cell 20):

We don't want to export. We want to use. ... We are better off using it. That's why we then changed that habit because we're using what we generate. We could change our habits more really, if we thought about it. Probably.... We were generating and not really thinking about it It was after we got that box [the IHD] that identified green, amber, and red that literally the next day our habits changed. It was quite drastic... That's only been recently that I thought about that one but it was just changing the habit from putting [appliances]on at night to putting them on through the day. Changing the habit of putting it on at night. (DL13 - PV + IHD)

Governing the conduct of electricity use in line with smart grid logics requires that adjustments are made to everyday life. Scholars have suggested that practices such as 
laundry and dish washing are constituted by materials, ideas and competences (Shove et al., 2012). In this case, we find that the governing of solar households as smart energy users is taking place through interventions that serve to equip these practices differently, adjusting the assemblage that enables the performance of practices. First, the new devices and artefacts introduced as part of the intervention serve to reassemble the material constitution of practice. Second, as new ideas of what 'good' and 'valuable' forms of solar generation and use come to be circulated and normalised as part of the self-governing of PV, households seek to translate these ideas in relation to their use of the existing sociomaterial fabric of the home. As a consequence, the previously unused capacities and functions of devices (such as timer switches) are utilised so that, to a greater or lesser extent, practices can be performed in ways that are regarded as optimal in relation to using solar electricity on site. Through these means, we find that the logic of 'solar as smart' serves to create new forms of flexibility about how, when and how much electricity is used. As and when these forms of self-government lead to the rerouting of household rhythms so that practices are removed from the evening peak (e.g. washing clothes, dishwashers), this in turn provides a potentially valuable resource for network operators, reducing the risks of voltage imbalance and steady-state voltage rise (Wang et al., 2012).

Enhanced displays.. The extent to which practices became equipped to realise flexibility differed between the two different parts of Test Cell 20. In the PV + IHD intervention, participants had already installed PV and were given a display device that communicated the power import or export status and accompanying literature that provided an explanation of the financial and grid benefits of using power on site. We found that these were effective in together establishing modest modifications in how individuals perform certain practices. Here, the IHDs provided a locally present visualisation of households current electrical 'state' and its meaning in relation to the grid at large, with green lights signifying that they were net exporting power and red lights indicating that they were net importing power. The simple messaging - of 'green for go' - encouraging them to make more use of their power during the generating periods was readily understood and in many cases adopted and internalised as being the optimal way to manage solar power:

(When asked about leaving items on standby) Not after the solar panel, which went in ... we were generating, we didn't really think about it. It was after we got that box, that identified to us green and the red, that literally next day changed our habits. (HS01 PV + IHD)

I'm in green which means I'm generating more than I'm using. ... So whenever it's on green we stick a big appliance on and you are more or less getting that electricity free cause we're generating it. Then obviously at night... it's all red because we're not. When I went to bed I was putting a wash on and dishwasher on and then obviously realised that that wasn't generating any power at that point. (DL13 PV + IHD)

The quotations show how the presence of the IHD has served to draw connections between PV generation and domestic appliances, reconstituting the sociomaterial assemblage through which practices unfold. Important here is the engagement with the rhythms of the production of solar energy as a resource, so that practices are realigned to accommodate the presence and absence of sunlight:

I try and I'll even cook things when the sun shines or get a shower when the sun's shining if I can... I'll fill the washer up tonight and in the morning...put it on a timer [on the washing machine]... and it'll be timed to come on later in the day when the sun shines. ... If the forecast is for a bright day that's what I'll do. (DL06, PV + IHD) 
Accompanying householders on 'energy tours' of their homes, we found that IHD + PV resulted in the normalisation of a number of solar 'technologies of the self' (Hörnqvist, 2010), including record keeping, logging energy use and placing the IHD in prominent positions such that it could participate in the everyday activities of the household. Yet, whilst the IHD was welcomed as a means through which participants could relate their solar generation to their own practices and to the grid at large, for a minority, the idea of being governed in this way was unwelcome and conscious forms of resistance arose, whereby such practices are actively dismissed, neglected and subverted, with one interviewee declaring: 'I am still more or less the same.... During the winter it doesn't make any difference at all' (HS09 PV + IHD).

Automatic hot water from excess PV. The second intervention within Test Cell 20 introduced hot water storage (HWS), a tank that would automatically absorb as much excess generation as possible which in turn would be used to supply hot water (but not heating) to the household and required much less active management. Forms of self-monitoring and calculation were much less prominent here than in the PV + IHD intervention, as might be expected. However, there was also a noticeable difference in the way that individuals brought aspects of their lives into alignment with the logic of solar as smart - the fit between the new devices and domestic practices was significantly different, creating alternative norm of what constituted optimal electricity conduct. Rather than reworking the assemblages of washing and dishwashing, it was showering that was most often modified as a result of the HWS being filled 'for free' during the day when the panels were generating and when other forms of domestic electricity use were low. The resulting hot water was then used for showering in the evenings in several households, even though they were not previously in the habit of showering the evening or during the day:

I try ... get a shower when the sun's shining if I can. Obviously if I am at work I'll get a shower in the evenings now. I just try and make full use of the solar panels. (DL17, PV + HWS)

... with the [automatic hot water system] if it happens to be a nice bright sunny day and you haven't had a shower in the morning you can have one in the afternoon knowing you're not going to be short of hot water the next day. (DL1502, PV + HWS)

By introducing plentiful hot water which can be efficiently stored, the automated system intervened in the home in a way which did not require the same active calculation of what optimal solar use would entail as those using the IHD were encouraged to develop. Instead, it presented optimal solar conduct as one of the storage and use of an abundant resource - hot water - which in turn served to reconfigure the times and ways in which hot water was used, the practices of which it was a part, and their meaning. In part, this was a result of the ways in which PV + HWS drew new connections between the availability of solar radiation and the practice of showering, requiring households to calculate the ways in which (forecasted) weather might impact on the resources available to undertake showering:

That does not heat water if there is no sunshine. I'm only getting one immersion heater operational in a dull weather. And that has a consequence. If it was really dull all day [wife and myself] we could not each have a shower without putting additional electricity into the system,... It's really a matter that we look at the weather forecasts, we look at the weather during the day. ... if neither of us had a shower on that particular day and it happened to be sunny, that amount of hot water would still be available the next day. We've got to take into consideration the weather conditions. (DL1502-PV + HWS) 
Both the PV + IHD and PV + HWS interventions have served to reconfigure the "webs of social and material structures which frame present and future practices' (Ropke and Christensen, 2013) and realign the entities of which practices are composed, creating new subject positions regarding 'what it makes sense to do' (Strengers, 2011) in relation to electricity conduct. In employing household decisions and deliberations about how to relate their practices to the uncertainties of renewable generation, we find that smart grid logics operate through techniques of self-government rather than central control, and come to rely at least as heavily on technologies of the self as on orchestration of an assemblage of wires, machines and devices for their realisation. Central to these projects are, we argue, the cultivation of dispositions, which can act to manage the grid in a highly distributed manner. That this mirrors the topology of the imagined future grid is no coincidence; the emerge of distributed renewable generation at the ends of wires heralds the creation of a network of governance nodes that are in a very real sense 'on-site' rather than being located in the traditional 'power stations' of central and regional energy government.

\section{Conclusions}

Far from being secure technological accomplishments or blueprints for the planning of electricity networks, we have argued that smart grids can most readily be understood as a new set of governmental programmes that seek to deploy a logic of managing demand in relation to supply in order to respond to challenges of decarbonisation, decentralisation and the financing of infrastructure provision. In this paper, we have sought to examine the workings of smart grid as comprised of rationalities and techniques that seek to work on the conduct of households in the UK, focusing on the ways in which domestic PV generation has come to be regarded as a potential site for intervention. In order to understand these processes, we turned to theories of governmentality and social practices, arguing that the concern within the field of governmentality with the conduct of conduct provides a means through which to engage with the ways in which everyday practices are not only emergent but are orchestrated through attempts to improve various spheres of social life. Governing, from this perspective, does not proceed through rules imposed from above, but works through the disposition of sociomaterial configurations through which conducts unfold and accompanying processes of normalising what constitute both acceptable and optimal forms of conduct. Viewed from this perspective, smart grids, as governmental programmes, intervene not only at the scale of the network but also through recomposing the ways in which everyday practices are conducted.

Drawing on our work with the CLNR project in the UK, we find that there are two facets of the governing of solar energy that are becoming central to the workings of the smart grid. First, whilst the initial economy of domestic solar production emphasised its optimisation in financial terms, the changing nature of this landscape means that 'good' electricity conduct is increasingly being regarded as that which minimises the import of nonsolar electricity into the home and maximises it local use. Second, where new interventions are taking place which seek to embed the logic of solar as requiring smart electricity use, we find that households are developing and employing techniques for self-government that accord with optimising their personal use of the PV electricity that they generate. These forms of self-government are achieved by creating connections between electricity generation, household appliances, daily routines and solar resources which serve to constitute new sociomaterial assemblages for everyday practices. In changing how, when and to what extent, solar generation is used locally, such practices serve not only to create changing household economies of energy 
use and financial investment but also to realign the relations of demand and supply embodied in current dominant forms of electricity provision.

Yet despite these findings, analysis from the CLNR project shows that households with solar electricity generation are similar to the majority of nonsolar households in terms of their patterns of electricity use (Bulkeley et al., 2015). Whilst the households investigated in this paper provide evidence of the possibilities of new ways of thinking about and using solar electricity, the extent to which this is having an impact on their levels of electricity consumption remains moot. We suggest that as attempts to realise smart grid logics gather pace, it will be critical to engage further with the ways in which the particular techniques through which they are being constituted, realised and resisted are taking place in everyday practice. Attempts to change the patterns of solar electricity use may, for example, need to be accompanied by interventions that seek to reduce overall consumption where solar households are already high electricity consumers rather than simply focusing on encouraging on-site use. In short, for the forms of demand management seen to be valuable at the distribution grid level to work, demand reduction may also be necessary.

The research also calls for a wider awareness of the currently suboptimal ways in which PV is being used and sold. We have shown here that through new forms of assembling grid configurations, household technologies and everyday practice, solar PV can be better used and 'investments' in PV made to deliver better returns for all parties through on-site electricity use. Yet such interventions remain the exception rather than the norm, and concentrated in demonstration projects that may not be able to scale up or extend in the current climate of electricity market regulation. Overcoming this is not simply a matter of 'awareness raising' amongst the public. For these new interventions depend on the configuration of all parties involved through new forms of sociotechnical relation that encourage connections between the timing of electricity generation and use of energy, and between energy services such as hot water, heat and the availability of natural resources (in this case sunshine). Such configurations and the processes through which they might be garnered are alienated under the currently dominant mode of energy supply and the associated market mechanisms that make it possible to consume energy or generate it without regard for the system of provision. On-site use of solar electricity, accomplished through interventions that are able to draw together different forms of agency and rationality, has the potential to powerfully reconnect the estranged practices of energy consumption and production with potentially significant consequences for the grid and for households.

\section{References}

Abi-Ghanem D and Hagget C (2011) Shaping people's engagement with microgeneration technology: The case of solar photovoltaics in UK homes. In: Devine-Wright P (ed.) Renewable Energy and the Public: from NIMBY to Participation. London: Earthscan, pp. 149-166.

Barry A and Slater D (2002) Technology, politics and the market: An interview with Michel Callon. Economy and Society 31(2): 285-306. DOI: 10.1080/03085140220123171.

Barry A (2013) Material Politics: Disputes Along the Pipeline. Wiley.

Bolton P (2013, September 27) Energy prices - Commons library standard note. UK Parliament. Available at: http://www.parliament.uk/briefing-papers/SN04153/energy-prices (accessed 10 March 2015).

Bulkeley H and Schroeder H (2011) Beyond State/Non-State Divides: Global cities and the governing of climate change. European Journal of International Relations 18(4): 741-764.

Bulkeley H, Watson M and Hudson R (2007) Modes of governing municipal waste. Environment and Planning A 39(11): 2733-2753. DOI: 10.1068/a38269 
Bulkeley H, Whitaker G, Matthews P, et al. (2015) High Level Summary of Learning: Solar PV Customers. Customer Led Network Revolution. Available at: http://www.networkrevolution. co.uk/project-library/high-level-summary-learning-solar-pv-customers/ (accessed 10 March 2015).

Callon M, Méadel C and Rabeharisoa V (2002) The economy of qualities. Economy and Society 31(2): 194-217. DOI: $10.1080 / 03085140220123126$

Chappells H and Shove E (2004) Infrastructures, crises and the orchestration of demand. In: Southerton D, Chappells H and van Vliet B (eds) Sustainable Consumption: The Implications of Changing Infrastructures of Provision. Edward Elgar Publishing Limited.

Department for Energy and Climate Change (2013) Feed-in Tariff Generation Statistics - Statistical Data Sets - GOV.UK. Available at: https://www.gov.uk/government/statistical-data-sets/feed-intariff-generation-statistics. (accessed 10 March 2015).

Foucault M (2000) Power. In: Faubion Robert JDA-G (ed.) New York: New Press; Distributed by W.W. Norton. Available at: http://www.amazon.com/Power-Essential-Works-Foucault-1954-1984/ dp/1565847091 (accessed 10 March 2015).

Foucault M (2009) Security, Territory, Population: Lectures at the Collège de France 1977-1978. New York: St Martins Press.

Hörnqvist M (2010) Risk, Power and the State: After Foucault (p. 186). Routledge. Available at: http:// books.google.co.uk/books?id=arT21WreExsC (accessed 10 March 2015).

Hughes TP (1993) Networks of Power: Electrification in Western Society, 1880-1930 (p. 488). The Johns Hopkins University Press. Available at: http://www.amazon.com/dp/0801846145 (accessed 10 March 2015).

Keirstead J (2007) The UK domestic photovoltaics industry and the role of central government. Energy Policy 35: 2268-2280.

Lehtonen M and Nye S (2009) History of electricity network control and distributed generation in the UK and Western Denmark. Energy Policy 37(6): 2338-2345. DOI: 10.1016/j.enpol.2009.01.026

Li TM (2007) Practices of assemblage and community forest management. Economy and Society 36(2): 263-293. DOI: $10.1080 / 03085140701254308$

Lockwood M and Davidson J (2010) Environmental governance and the hybrid regime of Australian natural resource management. Geoforum 41(3): 388-398. DOI: 10.1016/j.geoforum.2009.12.001

Louth N (2013, September 26) Are solar panels a good investment? MoneyWise. Available at: http:// www.moneywise.co.uk/home-mortgage/improvements/are-solar-panels-good-investment (accessed 10 March 2015).

MacKenzie D (2008) An Engine, Not a Camera: How Financial Models Shape Markets (p. 377). University Press Group Limited. Available at: http://books.google.co.uk/books?id= kD3JRwAACAAJ (accessed 10 March 2015).

Mitchell T (2008) Rethinking economy. Geoforum 39(3): 1116-1121. DOI: 10.1016/ j.geoforum.2006.11.022

Murdoch J (2000) Space against time: Competing rationalities in planning for housing. Transactions of the Institute of British Geographers 25(4): 503-519. DOI: 10.1111/j.0020-2754.2000.00503.x

Raco M (2003) Governmentality, subject-building, and the discourses and practices of devolution in the UK. Transactions of the Institute of British Geographers 28(1): 75-95. DOI: 10.1111/14755661.00078

Reckwitz A (2002) Toward a theory of social practices: A development in culturalist theorizing. European Journal of Social Theory 5: 243-263.

Ropke I and Christensen TH (2013) Transitions in the wrong direction? In Shove E and Spurling N (eds) Sustainable Practices Social Theory and Climate Change. Abingdon, Oxon; New York, NY: Routledge. Available at: http://public.eblib.com/EBLPublic/PublicView.do?ptiID=1157759 (accessed 10 March 2015).

Rutherford J and Coutard O (2014) Urban energy transitions: Places, processes and politics of sociotechnical change. Urban Studies 51(7): 1353-1377.

Rutland T and Aylett A (2008) The work of policy: Actor networks, governmentality, and local action on climate change in Portland, Oregon. Environment and Planning D: Society and Space 26(4): 627646. Available at: http://www.envplan.com/abstract.cgi?id=d6907 (accessed 10 March 2015). 
Rydin Y, Turcu C, Guy S, et al. 2013) Mapping the coevolution of urban energy systems: Pathways of change. Environment and Planning A 45(3): 634-649. DOI: 10.1068/a45199

Schatzki T (1996) Social Practices. A Wittgensteinian Approach to Human Activity and the Social. Cambridge: CUP.

Shove E (2010) Beyond the ABC: Climate change policy and theories of social change. Environment and Planning $A$ 42(6): 1273-1285-1273-1285. Available at: http://www.envplan.com/ abstract.cgi?id=a42282 (accessed 10 March 2015).

Shove E, Pantzar M and Watson M (2012) The Dynamics of Social Practice Everyday Life and How it Changes. Los Angeles: SAGE. Available at: http://site.ebrary.com/id/10568302 (accessed 10 March 2015).

Shove E and Walker G (2010) Governing transitions in the sustainability of everyday life. Research Policy 39(4): 471-476. Available at: http://www.sciencedirect.com/science/article/pii/ S0048733310000338 (accessed 10 March 2015).

Smith A, Kern F, Raven R, et al. (2013) Spaces for sustainable innovation: Solar photovoltaic electricity in the UK. Technological Forecasting and Social Change 81: 115-130. DOI: 10.1016/ j.techfore.2013.02.001

Smith SJ (2008) Owner-occupation: At home with a hybrid of money and materials. Environment and Planning A 40(3): 520-535. DOI: 10.1068/a38423

Spaargaren G (2011) Theories of practices: Agency, technology, and culture. Exploring the relevance of practice theories for the governance of sustainable consumption practices in the new world-order. Global Environmental Change 21: 813-822.

Strengers Y (2011) Beyond demand management: Co-managing energy and water practices with Australian households. Policy Studies 32(1): 35-58. Available at: http://rsa.informaworld.com/ srsa $/ 678365032-97667061 /$ content $\sim$ content $=a 932769042 \sim \mathrm{db}=$ all $\sim$ jumptype $=$ rss

Verbong GPJ, Beemsterboer S and Sengers F (2013) Smart grids or smart users? Involving users in developing a low carbon electricity economy. Energy Policy 52: 117-125.

Walters W (2012) Governmentality Critical Encounters (p. 188). London: Routledge. Available at: http://books.google.co.uk/books?id=u3DAcQAACAAJ

Wang P, Yi J, Lyons P, et al. (2012). Customer led network revolution - Integrating renewable energy into LV networks using energy storage. In: CIRED Workshop, Lisbon, 29-30 May 2012. Available at: http://www.ncl.ac.uk/eee/research/publication/192926 (accessed 10 March 2015).

Which (2013) Is solar PV a good investment? Which? Available at: http://www.which.co.uk/energy/ creating-an-energy-saving-home/guides/how-to-buy-solar-panels/is-solar-pv-a-good-investment/ 